\title{
The Induction of the Enzymes of Naphthalene Metabolism in Pseudomonads by Salicylate and 2-Aminobenzoate
}

\author{
By E. A. BARNSLEY \\ Department of Biochemistry, Memorial University of Newfoundland, \\ St John's, Newfoundland AI C ${ }_{5} S_{7}$, Canada
}

(Received 26 September I974; revised I3 January 1975)

\section{INTRODUCTION}

Naphthalene oxygenase is induced in certain Pseudomonas species by growth on salicylate, and may be induced gratuitously by 2-aminobenzoate or by 2-hydroxybenzyl alcohol in cultures growing on succinate (Shamsuzzaman \& Barnsley, 1974a). The induction of a number of enzymes responsible for the conversion of naphthalene to non-aromatic products (Davies \& Evans, I964) has now been measured in Pseudomonas NCIB98I6 and Pseudomonas putida (strains PpG7 and ATCCI7483) grown on succinate, or an inducer of naphthalene oxygenase. This paper reports these observations and discusses the regulation which may be involved.

\section{METHODS}

Organisms and culture media. Pseudomonas NCIB98I6 was obtained from the National Collection of Industrial Bacteria, and Pseudomonas putida (strain ATCCI7483) was obtained from the American Type Culture Collection. Strain Ppg7 of Pseudomonas putida (Dunn \& Gunsalus, 1973), a gift from Dr I. C. Gunsalus, was derived originally from the collection of Stanier, Palleroni \& Doudoroff (I966) (strain I I I), and was deposited by the latter authors in the American Type Culture Collection as ATCCI7485. Samples of ATCCI7485 obtained directly from the American Type Culture Collection could not be induced to oxidize naphthalene, and nor could a copy of strain II I kindly provided by Dr M. Doudoroff.

Carbon sources, 2-aminobenzoate, and the basal mineral medium used for cultures of NCIB98I 6 and ATCCI 7485 were prepared as described by Shamsuzzaman \& Barnsley (I974a). Pseudomonas putida tended to clump during the early phase of growth in this mineral medium, and the effect was particularly pronounced with PpG7. Consequently, the mineral medium of Jacobson, Bartholomaus \& Gunsalus (1966) was used for the latter organism.

Culture of cells and preparation of cell extracts. Cultures $(400 \mathrm{ml})$ were grown at $25^{\circ} \mathrm{C}$ in I 1 flasks shaken at $150 /$ osc./min in a New Brunswick Scientific G76 shaker. Solutions of inducers or other carbon compounds, sterilized by filtration, were added during the early exponential phase of growth (apparent extinction about 0.2 at $600 \mathrm{~nm}$ measured with $\mathrm{I} \mathrm{cm}$ cuvettes in a Perkin Elmer-Coleman I 24 spectrophotometer), and after the population had doubled, about twice the cells were collected by centrifugation at $6000 \mathrm{~g}$ for $20 \mathrm{~min}$ at $2{ }^{\circ} \mathrm{C}$. The bacterial pellet was washed in ice-cold $50 \mathrm{~mm}$-potassium dihydrogen phosphate$\mathrm{NaOH}$ buffer $\mathrm{pH} 7.0$ and resuspended $\left(\mathrm{O}^{\circ} \mathrm{I} \mathrm{g}\right.$ wet $\left.\mathrm{wt} / \mathrm{ml}\right)$ in phosphate buffer. Part of the suspension was disrupted with an ultrasonic oscillator (Model I85, Heat Systems-Ultrasonics, Inc., Plain View, New York, U.S.A.) at a nominal power of $60 \mathrm{~W}$. A portion (3 to $4 \mathrm{ml}$ ) initially at $0{ }^{\circ} \mathrm{C}$ was disrupted for four 0.5 min periods. Each period of disruption was 
followed by I min during which the disrupted cells and oscillator probe were cooled in ice water. The preparation was then centrifuged at $40000 \mathrm{~g}$ for I h at $4{ }^{\circ} \mathrm{C}$, and the supernatant was stored on ice.

Determination of naphthalene oxygenase. The spectrophotometric method of Shamsuzzaman \& Barnsley (1974a) using whole cells was employed. The results were not corrected for salicylate accumulation and therefore represent minimal values.

Determination of salicylate hydroxylase (EC. I. I4. I3. I). Method I. A procedure similar to that of Yamamoto et al. (I965) was used. To $2.45 \mathrm{ml}$ phosphate buffer $\mathrm{pH} 7 \cdot 0$ at $25^{\circ} \mathrm{C}$

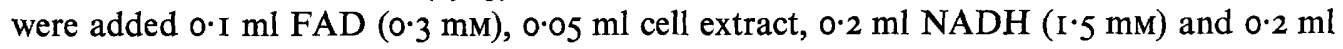
sodium salicylate $(\mathrm{I} .5 \mathrm{~mm})$, and the rate of decrease in extinction at $340 \mathrm{~nm}$ was measured. The rate was corrected for the rate of oxidation of NADH which occurred independently of added salicylate, and enzymic activity was calculated using an extinction coefficient of $6.22 \mathrm{~mm}^{-1} \mathrm{~cm}^{-1}$. The concentration of FAD used in this determination (IO $\mu \mathrm{M}$ ) is very much higher than the $K_{m}(0.07 \mu \mathrm{M})$ reported by Yamamoto et al. (1965) for the purified enzyme from a Pseudomonas species. Though added FAD was not always necessary to give the

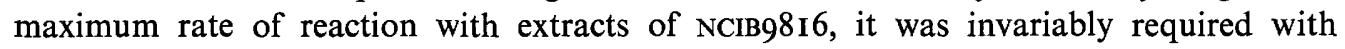
extracts of PpG7. Extracts of ATCCI 7483 appeared to contain no enzymic activity when assayed by this method, and so the following polarographic determination was used.

Method 2. To $\mathrm{I} .85 \mathrm{ml}$ of phosphate buffer $\mathrm{pH} 7.0$ at $25^{\circ} \mathrm{C}$ were added $0.033 \mathrm{ml} \mathrm{FAD}$ $(0.6 \mathrm{~mm}), 0.033 \mathrm{ml} \mathrm{NADH}(6.0 \mathrm{~mm})$ and $0.05 \mathrm{ml}$ of cell extract. The salicylate-independent rate of oxygen uptake was measured for $2 \mathrm{~min}$, and then $0.033 \mathrm{ml}$ sodium salicylate $(6.0 \mathrm{mM})$ was added. The rate of oxygen uptake was measured, corrected for the salicylate-independent uptake, and the enzymic activity was calculated assuming an initial $\mathrm{O}_{2}$ concentration of $0.25 \mathrm{~mm}$.

Determination of other enzymes. Salicylaldehyde dehydrogenase and I,2-dihydroxynaphthalene oxygenase (Shamsuzzaman \& Barnsley, I974b), catechol I,2-dioxygenase (EC. I. I3. I I. I) (Hegeman, I966) and catechol 2,3-dioxygenase (EC. I. I3 . I I. 2) (Feist \& Hegeman, 1969) were determined by published methods. Catechol 2,3-dioxygenase was determined immediately a supernatant was obtained.

\section{RESULTS AND DISCUSSION}

Table I gives the levels of enzymes in whole cells and extracts of NCIB98 I6, ATCCI 7483 and PPG7, respectively, under various conditions of growth. In all cases the presence of 2aminobenzoate or salicylate caused the induction of naphthalene oxygenase, I,2-dihydroxynaphthalene oxygenase, salicylaldehyde dehydrogenase, and salicylate hydroxylase. In ATCCI 7483 and PpG7, catechol 2,3-dioxygenase was also induced. 2-Aminobenzoate must have induced gratuitously for its concentration in the medium, determined as described by Shamsuzzaman \& Barnsley (I974a), remained unchanged during the growth of the culture to the stationary phase. Gratuitous induction of salicylate hydroxylase in NCIB98I6 was not noted earlier because extracts were not fortified with FAD.

The induction of all these enzymes by a gratuitous inducer also suggests that they may be co-ordinately induced, but confirmation of this in terms of a constant proportionality of enzyme levels and a common time course of induction (compare Ornston, 1966) is lacking due to technical difficulties in the measurement of theactivities of enzymes in complex mixtures.

The possibility of the co-ordinate regulation of the enzymes which convert naphthalene to 2-hydroxymuconic semialdehyde is of particular interest as Dunn \& Gunsalus (I973) 
Short communication

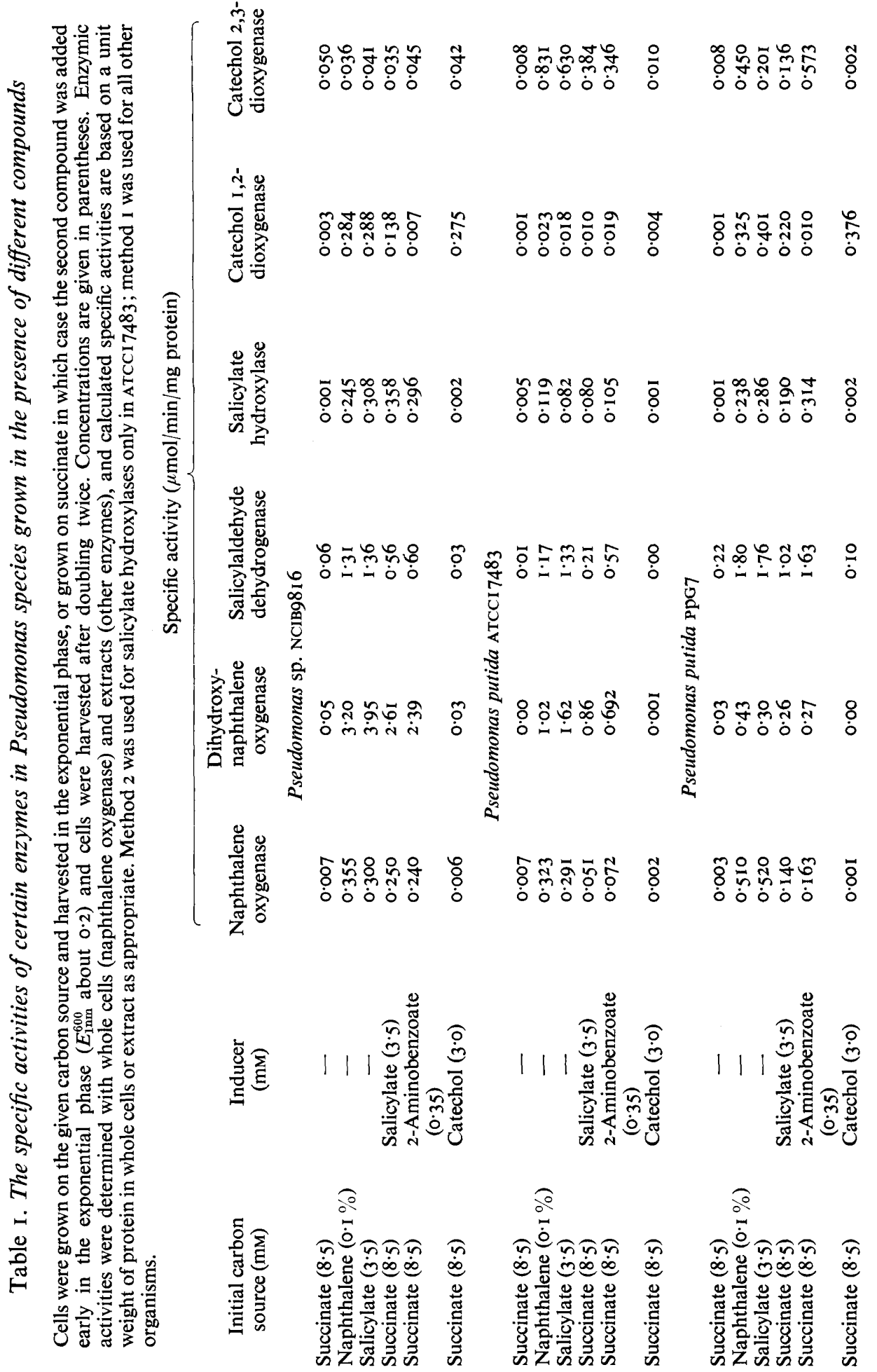


have demonstrated that the genes which specify the enzymes for these reactions in PpG7 are plasmid borne. Enzymes further along the degradative pathway have not been examined, but Chakrabarty (1972) showed that in certain other pseudomonads the genes for salicylate degradation through catechol and the meta pathway are also plasmid borne. An extension of the present observations and an examination of the possible homology of the naphthalene and salicylate plasmids would be of the greatest interest.

Note added in proof. Dr P. A. Williams kindly informed the author (personal communication) of his use of $10 \%$ acetone to stabilize catechol 2,3-dioxygenase in extracts of NCIB98I6, but I have not been able to confirm the induction of this enzyme.

I thank the N.R.C. of Canada for a research grant, Dr I. C. Gunsalus and Dr M. Doudoroff who kindly provided bacterial strains, and A. K. Leung and G. W. Symonds for technical assistance.

\section{REFERENCES}

Chakrabarty, A. M. (1972). Genetic basis of the biodegradation of salicylate in Psendomonas. Journal of Bacteriology II2, 81 5-823.

Davies, J. I. \& Evans, W. C. (I964). Oxidative metabolism of naphthalene by soil pseudomonads. The ring fission mechanism. Biochemical Journal 9r, 25I-26I.

Dunn, N. W. \& Gunsalus, I. C. (1973). Transmissible plasmid coding early enzymes of naphthalene oxidation in Pseudomonas putida. Journal of Bacteriology 114, 974-979.

Feist, C. F. \& Hegeman, G. D. (1969). Phenol and benzoate metabolism by Pseudomonas putida: regulation of tangential pathways. Journal of Bacteriology 100, 869-877.

Hegeman, G. D. (I966). Synthesis of the enzymes of the mandelate pathway by Pseudomonas putida. I. Synthesis of enzymes by the wild type. Journal of Bacteriology 91, I I40-I I 54.

Jacobson, L. A., Bartholomaus R. C. \& Gunsalus, I. C. (I966). Repression of malic enzyme by acetate in Pseudomonas. Biochemical and Biophysical Research Communications 24, 955-960.

Ornston, L. N. (1966). The conversion of catechol and protocatechuate to $\beta$-keto adipate by Pseudomonas putida. Journal of Biological Chemistry 241, 3800-3810.

Shamsuzzaman, K. M. \& Barnsley, E. A. (1974a). The regulation of naphthalene oxygenase in pseudomonads. Journal of General Microbiology 83, I65-1 70.

Shamsuzzaman, K. M. \& Barnsley, E. A. (1974 $b$ ). The regulation of naphthalene metabolism in pseudomonads. Biochemical and Biophysical Research Communications 60, 582-589.

Stanier, R. Y., Palleroni, N. J. \& Doudoroff, M. (I966). The aerobic pseudomonads: a taxonomic study. Journal of General Microbiology 43, I 59-27I.

Yamamoto, S., Katagiri, H., Maeno, H. \& Hayaishi, O. (I965). Salicylate hydroxylase, a monooxygenase requiring flavin adenine dinucleotide. I. Purification and general properties. Journal of Biological Chemistry 240, 3408-34I3. 